\section{НАРОДНАЯ МЕДИЦИНА ТУВИНЦЕВ ГЛАЗАМИ ВРАЧЕЙ (ПО МАТЕРИАЛАМ ОПРОСА ВРАЧЕЙ И ДРУГОГО МЕДИЦИНСКОГО ПЕРСОНАЛА В РЕСПУБЛИКЕ ТЫВА И СОСЕДНИХ РЕГИОНАХ)}

\author{
Наталья А. Вяткина \\ Институт этнологии и антропологии \\ им. Н. Н. Миклухо-Маклая \\ Российской академии наук, \\ Российская Федерация
}

TUVAN FOLK MEDICINE
THROUGH DOCTORS'
EYES: A SURVEY
OF PHYSICIANS AND
OTHER MEDICAL
PERSONNEL IN THE
REPUBLIC OF TUVA
AND ITS ENVIRONS

\author{
Natalia A. Vyatkina \\ Institute of Ethnology and Anthropology, \\ Russian Academy of Science, \\ Russian Federation
}

\begin{abstract}
Количество обращений пациентов к различным формам традиционных лечебных и профилактических практик в Туве растет и в некоторых случаях конкурирует с медициной западной - биомедициной. Статья посвящена исследованию влияния широко распространенных в Туве различных традиционных лечебных, профилактических и шаманских практик на взаимоотношения врача и пациента. Материалами выступили результаты опроса 2018 г. 22 врачей разных специальностей в Республике Тыва, а также в близлежащих регионах - Республике Хакасия, Алтайском и Красноярском краях. Были собраны мнения о разнообразных формах традиционных лечебных практик и народного целительства, которые распространены в регионах России с сильным этнокультурным компонентом.

Врачи соглашались на опрос на условиях анонимности и использовали самые разные термины для обозначения традиционных лечебных и профилак-
\end{abstract}

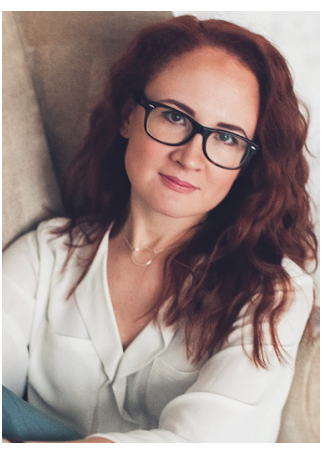

In the Republic of Tuva, people increasingly often appeal to various forms of traditional medical and preventive practices. In some cases, these practices even compete with Western medicine (biomedicine). The article is devoted to the study of the influence various traditional medical, preventive and shamanic practices, widespread in Tuva, have on the relationship between the doctor and the patient. Our study is based on the outcomes of a survey of 22 physicians of different medical specializations in the Republic of Tuva, as well as in the neighboring regions - the Republic of Khakassia, Altai and Krasnoyarsk regions - made in 2018. The opinions we have collected relate to various forms of traditional medical practices and folk healing common in the regions of Russia with considerable ethnic and cultural minority presence.

Physicians agreed to participate in the survey upon condition of strict anonymity and used a variety of

Вяткина Наталья Александровна - аспирант Центра медицинской антропологии Института этнологии и антропологии им. Н. Н. Миклухо-Маклая Российской Академии уаук. Адрес: 119991, Россия, г. Москва, Ленинский проспект, д. 32А, каб. 1804. Тел: +7 (495) 954-80-09. Эл. адрес: natalia.vyatkina@gmail.com. Научный руководитель - д. и. н. В. И. Харитонова.

Vyatkina Natalia Aleksandrovna, Postgraduate Student, Center for medical anthropology, Institute of Ethnology and Anthropology, Russian Academy of Sciences. Postal address: Room 1804, 32A Leninskiy prosp., Moscow, 119991 Russian Federation. Tel.: +7 (495) 954-80-09. E-mail: natalia.vyatkina@gmail.com. Supervisor - Doctor of History V. I. Kharitonova. 
тических практик, народного целительства. Все респонденты полагают, что применение альтернативных методов лечения не оправдано, первоочередным считают обращение к врачам. Все они верят в свое дело, в «настоящую» медицину. Причинами обращения пациентов к лекарям врачи называют: отсутствие эффекта от лечения в больницах, низкое качество предоставляемых там медицинских услуг, территориальную недоступность, дороговизну платных услуг, культурные особенности, семейные традиции и воспитание в туве и близлежащих регионах и пр.

Общее отношение к ним у врачей скептическое, хотя отдельные методы, например фитотерапию, медики не отвергают. Даже допускают применение подобных методов для себя и членов своих семей в домашних условиях или в специализированных учреждениях. Существенно отличаются мнения врачей Тувы, которые признают традиции культуры, в том числе и в лечении.

Ключевые слова: биомедицина; врач; пациент; традиционные медицинские практики; Тува; юг Сибири; Хакасия; Алтайский край; Красноярский край terms to refer to traditional medical and preventive practices or folk healing. All respondents told that alternative methods of treatment are unjustified, while medical advice is seen as the only key priority in healthcare. All of them believe in "real" medicine. When asked to name the main reasons why patients go to healers, physicians named the lack of treatment effect in hospitals, poor quality of medical services provided there, territorial inaccessibility, high cost of paid services, cultural characteristics, family traditions and education in Tuva and nearby regions, etc.

The general attitude of physicians to healers is skeptical, although some methods, such as herbal medicine, are not rejected outright. They also accept the use of such methods for themselves and their families, either at home or in specialized clinics. Widely different are the opinions of another group of physicians in Tuva - those who accept the special role of cultural traditions in healing, among other areas of human experience.

Keywords: biomedicine; physician; patient; traditional medical practices; Tuva; Southern Siberia; Khakassia; Altay Region; Krasnoyarsk Region

\section{Введение}

Современные реалии таковы, что изобилие всевозможных лекарских и целительских практик становится неотъемлемой частью здоровьесбережения. Особенно это характерно для регионов с ярко выраженными этнокультурными особенностями. Таким регионом, несомненно, является Республика Тыва. Количество обращений пациентов к различным формам традиционных лечебных и профилактических практик, особенно шаманскому целительству, растет в Туве с каждым годом, и в некоторых случаях конкурирует с медициной западной (биомедициной) (Харитонова, 2007). Можно по-разному относиться как к методам, так и к результатам использования пациентами альтернативных способов лечения, но факт остается фактом: число подобных обращений увеличивается. Востребованность этого рода услуг очень высока, и, если для кого-то существование профессионального народного целительства - это способ зарабатывания денег, то для других - возможность обеспечения личного и семейного благополучия. Местное население хорошо осведомлено, охотно посещает и регулярно обращается к этим практикам, это отмечают многие исследователи (см. напр.: Харитонова, 2010а; Пименова, 2007), также это прослеживается и при анализе анкет врачей в данном исследовании.

Медицинская антропология сегодня занимается исследованиями во множестве направлений. Одним из наиболее значимых представляется влияние социокультурных и этнокультурных факторов на взаимоотношения врача и пациента. Учет культурного разнообразия при общении с пациентами важен как на этапе сбора 
информации во время приема у врача, так и при постановке диагноза и планировании лечения. Эта статья посвящена исследованию влияния широко распространенных в Туве различных традиционных лечебных, профилактических и шаманских практик на взаимоотношения врача и пациента.

Автор посчитал необходимым и важным выяснить мнение представителей медицинских профессий об этом, особенно распространенном в Туве, феномене. Для сравнения были собраны мнения врачей в Республике Тыва и в близлежащих регионах - Республике Хакасия, Алтайском и Красноярском краях.

Материалом для данной статьи выступил качественный анализ серии глубинных интервью (личные беседы, опрос по электронной почте) с 22 представителями (12 женщин, 10 мужчин; возраст от 31 до 66 лет) различных врачебных специальностей из Тувы, Алтайского Края, Республики Хакасии и Красноярского края. В силу близости перечисленных регионов к Республике Тыва, а также в силу ярко выраженной этнокультурной специфики всего региона, автору показалось возможным получить более достоверные сведения, касающиеся в целом разнообразных традиционных лечебных и профилактических практик и народного целительства и отношения к ним медицинского сообщества, а также сравнить ответы врачей, коренных жителей Тувы с врачами прочих, затронутых исследованием, регионов. Всем врачам была предложена одинаковая для заполнения в электронном виде анкета из 25 вопросов.

Основной задачей данного исследования автор полагает выявление и интерпретацию мнений представителей биомедицинского сообщества о разнообразных формах традиционных лечебных практик и народного целительства, которые особенно распространены в регионах Российской Федерации с сильным этнокультурным компонентом (таким регионом, несомненно, является Республика Тыва). И если сами подобные практики, а также традиционные культуры активно исследуются на протяжении последних 60-ти лет этнологами, антропологами, культурологами и социологами, то точка зрения официальной медицины на применение и объяснение подобных методов лечения пока мало изучена.

\section{Этнокультурные особенности Тувы}

Тувинская традиционная культура и феномен шаманизма в Республике Тыва описаны многими исследователями: В.П.Дьяконовой (Дьяконова, 1972), С. И. Вайнштейном (Вайнштейн, 1990), Т. А. Ондар (Ондар, 1998), М. Б. Кенин-Лопсаном (Кенин-Лопсан, 2006, 2009), В. И. Харитоновой (Харитонова, 2006а). Обращение тувинцев к различным формам традиционных лечебных и профилактических практик, особенно к шаманскому целительству, в Республике Тыва широко распространено. И, хотя работа современных шаманских центров в Туве, прежде всего в г. Кызыл, рассчитана и на туристов (Харитонова, 2010b; Пименова, 2007), главные клиенты подобных заведений - местное население. Общение с врачами и пациентами, проживающими в Туве, Хакасии, Алтайском и Красноярском краях, а 
также с теми, кто бывал в этих регионах, позволяет с уверенностью говорить о том, что абсолютное большинство опрошенных сталкивались или имели опыт обращения к различным формам традиционных лечебных и профилактических практик и шаманского целительства; кто-то знает об этом лично, кто-то - со слов друзей, родственников, знакомых. Хотя, необходимо отметить, что многие врачи в силу их образования и деятельности с неохотой готовы обсуждать свой опыт столкновения с традиционными способами лечения или его последствиями, некоторые выводы об этом удалось сделать.

С исторической точки зрения можно рассматривать этапы в изучении и интерпретации этнокультурных особенностей Тувы. В советское время исследователи, как писал С. И. Вайнштейн, наблюдали в Советской Туве подъем культуры населения, успехи народного образования, здравоохранения, культурно-просветительской работы при одновременном отмирании религиозных верований (Вайнштейн, 1961). Тем не менее, эти выводы не оправдались. Ситуация в республике в постсоветский период и начале 2000-х в полной мере позволила наблюдать за расцветом магико-медицинских и религиозно-мистических представлений, а столицу Республики Тува уже тогда было принято считать «шаманской Меккой» (Харитонова, 2006b). Современное положение традиционной медицины в России см. подробно в работе В. И. Харитоновой (Харитонова, 2018).

Сегодня тувинцы охотно обращаются как в государственные клиники, так и активно посещают шаманские центры, что в республике считается обыденностью и подтверждается нашим исследованием. Шаманские центры в Туве имеют не только официальный статус ${ }^{1}$, но и помещения, в которых специалисты принимают. Одним из собственных официальных направлений деятельности они видят, наравне с ритуальной и семейно-обрядовой, активную лечебно-целительскую работу (Харитонова, 2010b).

\section{Термины и особые условия исследования}

Первое, что необходимо отметить: даже на этапе договоренностей об участии в исследовании многие врачи с неохотой соглашались развернуто отвечать на вопросы. Они также предупреждали, что, несмотря на неоднократные примеры контактов (в той или иной форме) с традиционными лечебными и профилактическими практиками, а также шаманским целительством или его последствиями (о чем будет сказано далее), распространяться о своем опыте они бы не хотели. Практически все готовы были участвовать в исследовании только на условиях анонимности.

Второе. В процессе сбора материала обнаружилась проблема разного понимания специфической терминологии у врачей и исследователя. Практики медицины использовали самые разные определения для обозначения народных практик

\footnotetext{
1 Речь идет о регистрации Местной религиозной организации шаманов (МРОШ) согласно Федеральному Закону №125 (ред. от 05.02.2018) «О свободе совести и религиозных объединениях» (Ф3-125, Электр. ресурс).
} 
целительства и своей области. В анкетах многие врачи заметно путались и упоминали «традиционную» и «нетрадиционную медицину», как равнозначные, в противовес западной (или в некоторых анкетах «официальной», а у кого-то «классической» - государственной).

В этнологической среде еще в середине прошлого века существовала похожая путаница в терминологии, но после выхода статьи Ю. В. Бромлея и А. А. Воронова (Бромлей, Воронов, 1976) устные и письменные формы медицин были упорядочены и классифицированы. Поэтому для современных медицинских антропологов есть биомедицина (наука, объединяющая биологические, медицинские и физикохимические науки, обеспечивающие формирование основ клинической медицины (Каркищенко, 2006)), есть народная медицина (основанная на устных формах не только передачи информации, но и бытования, функционирования, сохранения медицинского знания), есть традиционная письменная медицина (как, например, китайская, в основе которой лежат многочисленные источники и четкая система обучения).

Более того, медицинские антропологи в своих исследованиях активно используют термины «народное целительство», «неконвенциональная медицина» и, в целом, склонны использовать термин «медицина» во множественном числе (Харитонова, 2014: Электр. ресурс).

В данном исследовании автор предлагает выделять «биомедицину», как медицину официальную, и рассматривать различные варианты лечебных и профилактических систем и практик, включая народное целительство.

\section{Скепсис, скепсис и еще раз скепсис}

В данном исследовании мы пытались выяснить отношение респондентов в целом к различным формам традиционных лечебных и профилактических практик и народному целительству. Формулировки вопросов выглядели следующим образом: «Как Вы относитесь ... », «Чем Вы объясняете .... », «Сталкивались ли Вы ... », «Как Вы оцениваете... », «Опишите случаи ... » и т. п. Первое, что явно бросалось в глаза, и что прослеживалось в ответах респондентов - это скепсис в отношении не биомедицинских методов лечения.

Врачи пенсионного возраста, с которыми удалось пообщаться в дополнение к основному исследованию, но которые работали в Туве или в регионах, расположенных в непосредственной близости, как, например, Хакасия, хотя и «повидали всякого», также оставались в своих ответах на стороне «официальной медицины» (биомедицины). Они даже эмоционально старались показывать, что шаманы, как и результаты их деятельности - это, скорее, что-то из категории сказок и легенд, возникших благодаря этнокультурной специфике региона. И именно в Туве, по их мнению, подобные методы традиционных и народных методов лечения исторически получили свое широкое распространение. 
В целом, во многих ответах врачей (в отдельных фразах и формулировках) прослеживается скепсис в отношении к различным формам лечебных и профилактических практик и народному целительству.

Характерен рассказ одного из хакасских врачей ${ }^{1}$ о своем пациенте:

- Ночь, кабинет неотложной стоматологической помощи. Заходит молодой человек, хакас 20 лет, приличной наружности с умными глазами. Жалобы: болит зуб, что только ни делал - не помогает. С мамой ездил к шаманке, выплюнул всех червяков. Вернулись домой - опять всё болит. Может, не все черви вышли?

С этого момента прошу подробностей, заинтриговал. Суть метода шаманки, у которой они побывали: в соответствующей обстановке (врач скептически оценивает созданный вокруг ритуала антураж. $-H$. B.) она зажигает траву, водит перед лицом, просит вдыхать. Потом мальчик выплёвывает червей.

По факту бабка обкурила пацана, предполагаю, беленой. Под наркотическим опьянением прошла боль и появились галлюцинации на заданную тему. Прошло опьянение - вернулась боль. Что поделать, бубен без травы не работает.

Врач видит молодого пациента «с умными глазами», для него молодость и ум уже противоречат необходимости обращения к шаманке. Также, в силу своего любопытства, врач пытается выяснить методику работы шаманки и объяснить ее (через доступные ему биомедицинские представления) наркотическим воздействием ядовитого растения белены. Но очевиден скепсис врача, его любопытство и однозначная интерпретация увиденного.

Подобное отношение не является единичным, многие из опрошенных врачей с сомнением отзывались о необходимости и обоснованности обращения пациентов к различным формам лечебных и профилактических практик и народного целительства. Они приводили такие примеры:

- Мужчина лечил (не в больнице. - H. В.) болезнь Бехтерева² около 20 лет, пока не умер.

- По уговору родственников обращались к знахарям для лечения заикания у ребенка. Без эффекта.

Но были и менее скептически настроенные участники исследования. Мнение врача из Красноярска:

- В своей практике я сталкивалась (с обращением пациентов к традиционным практикам лечения. - H. В.), но достаточно редко. Пациенты по-разному реагируют на рекомендации врачей. Как варианты: доверяют полностью; доверяют, но стараются самостоятельно «дополнить» лечение; не доверяют вообще и игнорируют рекомендации. Отсюда и стремление к народной медицине: некоторые в дополнение к рекомендациям врача назначают сами себе или с помощью народных целителей до-

${ }^{1}$ Здесь и далее ответы респондентов переданы без существенных правок.

${ }^{2}$ Болезнь Бехтерева - системное воспалительное заболевание соединительной ткани с преимущественным поражением суставно-связочного аппарата позвоночника, а также периферических суставов и вовлечением в процесс внутренних органов (сердце, аорта, почки) (Бехтерева болезнь, Электр. ресурс). 
полнительное лечение. Чаще всего - лечение травами. Это не так плохо, если человек попал к профессиональному травнику; но, в наше время, это практически невозможно. Хуже, когда пациенты полностью игнорируют назначенное врачом лечение. Особенно при серьезных заболеваниях. Одно дело полоскать горло при простуде какой-нибудь чудодейственной травой, другое - лечить рак с помощью настоев трав.

Здесь мы видим готовность врача понимать желание пациента совместить медикаментозное лечение с фитотерапией. С другой стороны, что касается лечения «серьезных» заболеваний или, к примеру, в случаях полного игнорирования пациентами назначений врача при прочих диагнозах, применение пациентом различных форм целительства врачом воспринимается однозначно негативно.

\section{Почему не в больнищу?}

Если говорить об объяснении причин обращения пациентов к разнообразным формам традиционных лечебных и профилактических практик и шаманскому целительству, мнения участвовавших в исследовании врачей расходятся. Чаще всего респонденты упоминают отсутствие эффекта от лечения в государственных лечебно-профилактических учреждениях (ЛПУ), низкое качество предоставляемых там медицинских услуг, недоступность медицины, как в территориальном смысле (удаленность населенных пунктов), так и в финансовом, в целом разочарование в биомедицине, а также культурные особенности, семейные традиции и воспитание в Туве и близлежащих регионах.

Позволю себе привести мнение врача из Хакасии о тувинских пациентах:

- Но тувинцы эти (речь шла о пациентах дорогих клиник. - H. В.) - люди в большинстве своём образованные и приближенные к правящему клану. Кто к правящему клану не приближен, тот денег не имеет. Ну и лечится, наверное, у шамана.... Кто-то идет к шаманке, кто-то к бабке-гадалке. Вера в чудо присуща всем народам.

Здесь можно заметить причинно-следственную связь, которую выстраивает каждый врач для объяснения того, почему пациенты обращаются к различным формам лечебных и профилактических практик и народного целительства. Основное - это нехватка средств, второе - низкий уровень медицинской грамотности населения.

Многие врачи, участвовавшие в исследовании и не являвшиеся представителями Республики Тыва, говорили о том, что тувинцы вынуждены обращаться к лекарям и шаманам по разным причинам: от удаленности населенных пунктов до низкого качества ЛПУ в республике - но почти все врачи отметили специфику региона, культурные особенности и традиции Тувы.

Показателен обобщающий ответ одного из врачей-участников исследования о пациентах в целом:

- Почему пациенты обращаются к народным способам лечения? А) для обычного человека нет особой разницы в принципах и назначении методов лечения - 
главное, чтоб не болеть; Б) часто это бывает в случаях слабого эффекта (или его отсутствия) от классической медицины, либо в случаях возрастных (остеохондроз, артрозы) изменений, либо серьезных хронических заболеваний. Например, при явлении бесплодия ритуалы по повышению «женской» или «мужской» силы; В) особенности региона - недоступность или затруднения в получении классической медицинской (помощи. - H. В.).

Многие «винят» в вынужденном обращении пациентов к различным формам традиционных лечебных и профилактических практик и шаманскому целительству биомедицину, акцентируя внимание на отсутствии эффекта от лечения в ЛПУ:

- Отсутствие эффекта от традиционной (биомедицины. - H. В.) медицины, нежелание обследоваться, отсутствие преемственности у врачей разных специальностей в лечении пациента; каждый видит отдельно взятую проблему по своему профилю, а не в целом пациента и причину заболевания.

- Иногда недоступность медицины или недоверие.

- Отсутствие культуры заботы о своем здоровье; возможно, предыдущий негативный опыт общения с врачами.

- Возможно, низкое качество врачебной помощи в регионе, плюс отсутствие эффекта от медицинской помощи в лечебных учреждениях.

Другими словами, если бы качество врачебной помощи было выше, а также если бы эффект от медицинской помощи в ЛПУ был более ярко выражен (особенно при хронических заболеваниях костно-мышечной системы, что подчеркивалось несколькими врачами), то население меньше обращалось бы к целителям, шаманам, знахарям.

\section{Вера в свое дело}

Необходимо отметить, что все врачи, вне зависимости от региона, четко разделяют официальную медицину (биомедицину) и различные формы традиционных лечебных и профилактических практик и шаманского целительства. Они полагают, что применение подобных альтернативных методов лечения практически всегда не оправдано. Большинство опрошенных первоочередным считают обращение к врачам, а затем (в редких случаях и в качестве дополнения к основному лечению) допускают использование различных форм лечебных и профилактических практик и народного целительства.

Как врачи объясняют параллельное функционирование современной медицины (биомедицины) и практик традиционной и народной медицины? Некоторые врачи полностью отрицали сосуществование биомедицины и традиционных практик, как равнозначных в сфере здоровьесбережения:

- Я не думаю, что они успешно сосуществуют, результатов такого тандема я не встречала.

- Не соглашусь в отношении успешного сосуществования... Считаю, что ничего общего между медициной и практиками нет. 
При этом некоторые врачи допускают параллельное существование, наряду с биомедициной, различных форм традиционной медицины и народной медицины, шаманских практик и народного целительства:

- Я думаю, что они по крайней мере могут существовать параллельно.

- Они дополняют друг друга.

- Людям, пациентам, необходим лечебный эффект, уменьшение боли, продление молодости - здесь грань между западной и народной медициной стирается. Западная фармакология вышла из народного траволечения. Просто сегодня дозы препаратов стандартизованы и подтверждены испытаниями.

- На территории Сибири, там, где природа уживается с современным миром, вами указанные две ветви существуют бок о бок. Там, где нет цивилизации, и первая помощь не может подоспеть (вовремя. $-H$. B.), прибегают к традиционной медицине, чтобы оказать посильную поддержку до прибытия вертолетов и специалистов.

При этом, в целом, ответы опрошенных позволяют судить о безоговорочной вере врачей в свое дело, в «настоящую» медицину (биомедицину) в противовес народной и традиционной, в т. ч. широко распространенным в регионе и культурно значимым для тувинцев шаманским практикам.

\section{Иногда можно?}

При всей вере в биомедицину некоторые врачи все-таки допускают использование различных форм лечебных и профилактических практик и народного целительства, объясняя свое мнение «эффектом Плацебо» и «отдаленностью места проживания пациента».

Более того, многие врачи допускают применение подобных методов для себя и членов своих семей в домашних условиях или в специализированных учреждениях. На соответствующий вопрос они отвечали так:

- Если заваривать ромашку - традиционный способ лечения, то - да (использую. - H. В.).

- Ароматерапия (допустима. - H. В.) при ОРВИ.

- ... Если местное физиолечение расценивать как народный способ.

- Да, если считать применение меда, лимона, чеснока и тому подобного.

- Использую традиционную медицину. При обострении остеохондроза обращаюсь к китайской медицине.

- ... Массаж тригерных точек, рефлексотерапия.

- ... Дзю-терапия, полынные сигары.

Тувинские врачи упоминают об использовании артыша (можжевельника) в домашних условиях не только как природного антисептика, но и как магического средства для «изгнания злых духов»:

- Благовонь зажигаем часто дома. Родители (родители врача. - H. B.) травами иногда лечатся. 
- Я пользуюсь артышем. Он является природным антисептиком, благовониейароматизатором, также в народе верят в его силу отгонять злых духов.

- Я рекомендую родителям (заболевшего ребенка. - H. В.) зажигать благовонь можжевельник перед тем, как уложить ребенка спать. Это чтобы изгнать злых духов.

Если говорить о личных обращениях к шаманам и лекарям, большинство участвующих в исследовании врачей ответило на этот вопрос отрицательно.

При этом врачи обращаются к практикам традиционной китайской медицины, но лицензированным, имеющим квалификацию и юридическое разрешение:

- Сама обращалась к врачам китайской медицины (иглоукалывание, массаж, травы). Доверяю конкретному врачу-китайцу. В Китае лечилась в клинике, у которой имеется лицензия на медицинскую деятельность. К китайской медицине отношусь положительно.

Врачи из Республики Тыва описывают собственные случаи обращения к специалистам народной и традиционной медицины, шаманского целительства как к чему-то совершенно обыденному:

- Да, я пользуюсь. У тувинцев 12, 24, 36 (цикл 12 лет) считается опасным для жизни. В свои 24 года я весь год болела. Тогда мама прибегла к помощи знахаря. После его массажа мне стало лучше.

- Я прибегал к помощи шаманов для того, чтобы привлечь удачу и открытие дорог в сложных начинаниях.

- Недавно русская знахарка-бабушка вылечила меня от сотрясения головы. А 5 лет назад она мою дочь вылечила до предстоящей операции. Мы ее всем родственникам рекомендуем теперь.

Все это подтверждает тот факт, что Тува - это особенный регион с ярко выраженными этнокультурными особенностями и традициями.

\section{Тува - это свой мир}

Ответы респондентов, граничащих с Республикой Тыва, и ответы тувинских врачей, участвовавших в исследовании, разительно отличаются.

Например, врачам был предложен вопрос о приемлемости использования населением различных форм традиционных лечебных и профилактических практик и народного целительства.

Тувинский врач на это ответил так:

- Думаю, оправдано ... Я боюсь игнорировать народную медицину. Иногда, не дождавшись эффекта от западной медицины, (люди. - H. В.) прибегают к народным целителям. Причинами неэффективности (лечения в ЛПУ. - Н. В.) могут быть недостаточная квалифицированность врача, несоблюдение пациентом рекомендаций врача или же финансовая несостоятельность пациента. Лекарства все дороже и дороже, обследование тоже дается недешево в некоторых случаях. 
Помимо этого, для тувинцев абсолютно очевидно, что Тува - это особенный регион, в котором есть свои традиции, в том числе лечения:

- Да, так исторически сложилось. Традиционная культура и ход истории способствовали этому. В Туве многие тысячелетия ламаизм и буддизм гармонично сочетались. Ламы и шаманы у тувинцев всегда были в особенном почете у простого народа, они же были элитой общества. Есть версия, что тувинское слово «хам» (шаман. - H. В.) берет корень от слова «камгалакчы», что в переводе означает «спаситель», «хранитель». Он спасает, он помогает людям.

На вопрос о том, как врач понимает или догадывается, что пациент склонен обратиться или уже обращался к практикам традиционной и народной медицины, чаще всего врачи (не тувинцы) отвечают, что пациенты сами рассказывают о подобном своем опыте:

- Обычно пациенты сами говорят о том, что пытались лечиться другими способами. Снова к врачу их приводит страх (дальнейшего ухудшения самочувствия или осложнений. - Н. В.).

- Многие пациенты не скрывают своего обращения к народным способам лечения - кто-то совмещает прием официальных лекарственных средств со средствами народной медицины (для усиления эффекта лечения).

Но мнения врачей из Тувы снова выделяются среди мнений врачей из других регионов. Вот слова сельского врача:

- В селе многие ходят (к целителям. - H. В.). Тут гадать нечего. Особенно, отчаявшиеся родители. Когда ребенок сильно болеет, родители могут пригласить шамана в больницу, чтобы изгнал злых духов, сделал массаж (в основном, костоправы делают массаж). Врачи здесь не против, потому что знают, что они помогают. Иногда, когда сан-авиация долго не прилетает (в экстренных случаях из города прилетает на вертолете), я тоже вызываю шамана. Спасать ребенка надо, любыми способами. Мне потом с этим жить, спать. В городе такое невозможно. Там люди урбанизировались.

Ниже представлено мнение врача-педиатра из города Кызыл:

- Иногда они (пациенты) сами могут признаться. Я тоже могу спросить, потому что знаю, что многие ходят к ним. Это обыденность в Туве. Врачи тоже понимают, принимают силу народных целителей. Я даже больше скажу: врачи сами ходят к ним. В Кызыле контакты сильных народных целителей мы знаем, делимся их адресами. Правда, были случаи, когда врач ругает пациента из-за того, что тот прибегал к народным целителям. Есть и такие врачи. Такие врачи в основном в городах (Тувы. - Н. В.).

Почему после целителей пациент все-таки попадает к врачу? Тувинский врач объясняет слабый эффект от обращения к традиционным лечебным практикам и народному целительству самим отношением современных пациентов к ним: несоблюдение рекомендаций целителя и требование немедленных результатов все это, по мнению респондента, и вынуждает пациентов обращаться к биомедицине, как к более простому, понятному и быстрому инструменту сохранения и поддержания здоровья: 
- Сильные народные целители лечат все болезни. Некоторые болезни для лечения требуют следования четким правилам. Допустим, тот или иной отвар лучше пить утром в 7 часов и так далее, другой - через 40 минут после еды. Так организм лучше воспринимает полезные свойства. Есть такое понятие «часы активности» у органа. Многие люди не настроены соблюдать это все. Им лишь бы сейчас, немедленно вколоть что-нибудь, чтобы потом снова с головой уйти в работу.

Современные тенденции глобализации и урбанизации, ускорение темпа жизни в целом вызывает беспокойство тувинцев, особенно старшего поколения. Ниже реплика врача коренного жителя Тувы (возраст 61 год):

- Сейчас молодые врачи в Туве все реже верят народной медицине. Их учат западной медицине, голова полностью занята прочитанными книгами о западной медицине. Но настоящий врач должен чувствовать любую медицину, будь то западная или народная.

Ускорение темпа жизни, характерное для современных реалий в России и в мире, не обошло также и Республику Тыва. Хотя в удаленных регионах республики, все еще сохраняется прежнее отношение к жизни и размеренность, городская жизнь при этом претерпевает значительные изменения.

\section{Заключение}

Наше исследование, посвященное отношению врачей ряда сибирских регионов, в том числе Тувы, к традиционным и народным медицинским практикам, а также народному целительству, показывает сходные результаты исследований социологов медицины, посвященных изучению востребованности среди населения различных форм традиционных лечебных практик и народного целительства, например О. В. Музалевской (Музалевская, 2012). И хотя наше исследование не рассматривало непосредственно мнения пациентов, косвенно, через анализ мнений врачей, можно отметить совпадение объяснений причин обращения к традиционным и народным лечебным практикам.

Несмотря на привлекательность для пациентов государственного здравоохранения бесплатности услуг, наличие очередей, отношение персонала и низкое качество обслуживания были выделены среди негативных сторон. Таким образом, по данным О. В. Музалевской, услуги традиционной медицины (оказываемые в том числе в ЛПУ) востребованы в основном социально активными людьми, оптимистично оценивающими свой физический статус. Для них отсутствие очередей и вовлеченность врача в процесс лечения, а также заинтересованность последних в эффективности лечения, становится важнее необходимости оплачивать подобное лечение. Это подтверждается мнениями врачей в нашем исследовании: большинство респондентов говорят о низкой эффективности лечения в ЛПУ юга Сибири, иногда о недоступности биомедицины в удаленных районах, разочарованности пациентов от лечения в больницах и большей готовности в связи с этим к использованию альтернативных современной медицине практик лечения. 
Говоря об отношении врачей к различным формам народной и традиционной медицины и к шаманскому целительству, несомненно, мнение врачей Тувы следует выделять особо. Последние не только воспринимают эти методы как нечто обыденное, но и сами обращаются к шаманам, лекарям и используют различные характерные для Тувы практики дома (как, например, зажигание можжевельника). Врачи Тувы принимают как норму использование различных народных и традиционных медицинских практик, в т. ч. шаманского целительства.

Врачи других регионов более скептически и в какой-то степени ревностно относятся к своим, биомедицинским методам. Они верят в свое дело и обосновывают свою позицию значимостью медицинского образования и личным многолетним опытом работы. Но, важно отметить, что многие врачи полагают: выбор того или иного метода лечения - это личное право пациента. Они не исключают использования фитотерапии, рефлексотерапии, массажа и иглоукалывания. Впрочем, почти все опрошенные замечают, что рано или поздно, после целителей, знахарей и шаманов пациент обратится к ним.

Необходимо отметить также, что существование и активное функционирование различных форм традиционных лечебных и профилактических практик и народного целительства, особенно в регионах с ярко-выраженной этнокультурной спецификой, необходимо изучать не только с позиции культурологии и этнографии, но и позиции медицинской антропологии и социальной антропологии, принимая за факт современные реалии: параллельное сосуществование и успешное развитие различных медицинских систем, практик и методов.

\section{СПИСОК ЛИТЕРАТУРЫ}

Федеральный закон от 26.09.1997 N 125-Ф3 (ред. от 05.02.2018) "О свободе совести и о религиозных объединениях" (Электронный ресурс) // КонсультантПлюс. URL: http:// www.consultant.ru/document/cons_doc_LAW_16218/5d62cd14eedd618431cd9dbc8e4ed1e e64b0f7be/ (дата обращения: 28.08.2018).

Бехтерева болезнь (Электронный ресурс) // Большая медицинская энциклопедия. URL: http://бмэ.opг/index.php/БEXTЕРЕВА_БОЛЕЗНЬ (дата обращения: 06.08.2018).

Бромлей, Ю. В., Воронов, А. А. (1976) Народная медицина как предмет этнографических исследований // Советская этнография. № 5. С. 189 (3-18).

Вайнштейн, С. И. (1961) Тувинцы-тоджинцы: Историко-этнографические очерки. М. : Издательство восточной литературы. 218 с.

Вайнштейн, С. И. (1990) Очерк тувинского шаманства // Традиционная обрядность и мировоззрение малых народов Севера / отв. ред И. С. Гурвич, 3. П. Соколова. М. : ИЭА РАН. 221 с. С. $160-195$.

Дьяконова, В. П. (1972) К изучению шаманства у тувинцев (полевой сезон 1971 г.) // Краткое содержание докладов годичной научной сессии Института этнографии АН СССР / отв. ред. К. В. Чистов. Л. : Наука. 107 с. С. 27-28.

Каркищенко, Н. Н. (2006) Становление и развитие биомедицины // Биомедицина № 2. М. : ФГБУН «Научный центр биомедицинских технологий Федерального медикобиологического агентства» (ФГБУН НЦБМТ ФМБА России). 143 с. С. 5-17. 
Кенин-Лопсан, М. Б. (2006) Традиционная культура тувинцев. Кызыл : Тувинское книжное издательство. 232 с.

Кенин-Лопсан, М. Б. (2009) Тувинские шаманы. М. : Маска. 325 с.

Музалевская, О.В. (2012) Потребности населения в услугах традиционной медицины : дисс. ... канд. соц. н. В. 169 с.

Ондар, Т. А. (1998) Психологические функции шаманизма в современных социальных и политический процессах : дисс. ... к. псих. н. М. 134 с.

Пименова, К. В. (2007) Возрождение и трансформации традиционных верований и практик тувинцев в постсоветский период (основные проблемы) : дисс. ... к. ист. н. М. $310 \mathrm{c}$.

Харитонова, В. И. (2006а) Феникс из пепла? Сибирский шаманизм на рубеже тысячелетий. М. : Наука. 372 с.

Харитонова, В. И. (2006b) Немного о том, чем закончился «процесс отмирания религиозных верований» // Межэтнические взаимодействия и социокультурная адаптация народов Севера России / отв. ред. В. И. Молодин, В. А. Тишков. М. : ИЭА РАН. 382 с. C. 233-250.

Харитонова, В. И. (2007) Нет, это не я, это - богиня Кали!.. // Влияние религии на общество и личность / отв. ред. А. А. Велик. М. : ИЭА РАН. 309 с. С. 172-199.

Харитонова, В. И. (2010a) Шаманское целительство в современной России // V Международный форум «Интегративная медицина - 2010», Сборник тезисов и докладов: научное издание / М. : НИПКЦ Восход-А. 203 с. С. 108-112.

Харитонова, В. И. (2010b) Работа с сакральными знаниями и практиками: методико-методологический аспект // Этнографическое обозрение. № 3. С. 7-21.

Харитонова, В. И. (2014) Неконвенциональная медицина в современной России [Электронный ресурс] // Медицинская антропология и биоэтика. № 1 (7) URL: http:// www.medanthro.ru/?p=2017\%C2\%A0 (дата обращения: 26.08.2018).

Харитонова, В. И. (2018) Традиционная медицина в России: насущная необходимость или коммерческий проект? // Философские проблемы биологии и медицины. Вып. 12: Между биофилософией и биоэтикой: сборник статей. М. : Изд-во «Социально-гуманитарные знания». 340 с. С. 38-43.

Дата поступления: 12.09.2018 2.

\section{REFERENCES}

Federal'nyi zakon ot 26.09.1997 N 125-FZ (red. ot 05.02.2018) "O svobode sovesti i o religioznykh ob"edineniiakh" [Federal law of 26.09.1997 N 125-FL (ed. 05.02.2018) "On the freedom of conscience and religious associations"]. ConsultantPlus [on-line] Available at http://www.consultant.ru/document/cons_doc_LAW_16218/5d62cd14eedd618431cd9dbc8 e4ed1 ee64b0f7be/ (access date: 28.08.2018) (In Russ.).

Bekhtereva Bolezn' [Bechterew's disease]. Bol'shaia Meditsinskaia Entsiklopediia [on-line] Available at: http://бмэ.орг/index.php/БЕХТЕРЕВА_БОЛЕЗНЬ (access date: 16.08.2018) (In Russ.). 
Bromlei, Iu. V. and Voronov, A. A. (1976) Narodnaia meditsina kak predmet etnograficheskikh issledovanii [Folk medicine as a field of ethnographic research]. Sovetskaia etnografiia, no. 5, pp. 3-18. (In Russ.).

Vainshtein, S.I.(1961) Tuvintsy-todzhintsy. Istoriko-etnograficheskie ocherki [Tozhu Tuvans: historical and ethnographic essays]. Moscow, Nauka. 218 p. (In Russ.).

Vainshtein, S. I. (1990) Ocherk tuvinskogo shamanstva [An essay on Tuvan shamanism]. In: Traditsionnaia obriadnost' i mirovozzrenie malykh narodov Severa [Traditional ritual and worldview of the small peoples of the North]. Ed. by I. S. Gurvich and Z. P. Sokolova. Moscow, IEA RAS Publ. 221 p. Pp. 160-195. (In Russ.).

D'iakonova, V. P. (1972) K izucheniiu shamanstva u tuvintsev (polevoi sezon 1971 g.) [On the study of shamanism in Tuva (field season of 1971)]. In: Kratkoe soderzhanie dokladov godichnoi nauchnoi sessii Instituta etnografii AN SSSR [Summary of reports of the Institute of Ethnography at annual scientific session AS USSR], ed. by K. V. Chistov. Leningrad, Nauka Publ. 107 p. Pp. 27-28. (In Russ.).

Karkishchenko, N.N.(2006) Stanovlenie i razvitie biomeditsiny [The rise and development of Biomedicine]. Biomeditsina [Biomedicine], no. 2, pp. 5-17. (In Russ.).

Kenin-Lopsan, M. B. (2006) Traditsionnaia kul'tura tuvintsev [Traditional culture of Tuvans]. Kyzyl, Tuvan book publisher. 232 p. (In Russ.).

Kenin-Lopsan, M. B. (2009) Tuvinskie shamany [Tuvan shamans]. Moscow, Mask Publ. 325 p. (In Russ.).

Muzalevskaia, O. V. (2012) Potrebnosti naseleniia v uslugakh traditsionnoi meditsiny [The population's demand for the services of traditional medicine]. Diss. ... Candidate of Sociology. Volgograd. 169 p. (In Russ.).

Ondar, T. A. (1998) Psikhologicheskie funktsii shamanizma $v$ sovremennykh sotsial'nykh $i$ politicheskii protsessakh [Psychological functions of shamanism in modern social and political processes]. Diss. ... Candidate of Psychology. Moscow. 134 p. (In Russ.).

Pimenova, K. V. (2007) Vozrozhdenie i transformatsii traditsionnykh verovanii i praktik tuvintsev $v$ postsovetskii period (osnovnye problemy) [The revival and transformation of traditional beliefs and practices of Tuvans in the post-Soviet period: main problems]. Diss. ... Candidate of History. Moscow. 310 p. (In Russ.).

Kharitonova, V. I. (2006a) Feniks iz pepla? Sibirskii shamanizm na rubezhe tysiacheletii [The phoenix from the ashes? Siberian shamanism at the turn of the Millennium]. Moscow, Nauka Publ. 372 p. (In Russ.).

Kharitonova, V. I. (2006b) Nemnogo o tom, chem zakonchilsia "protsess otmiraniia religioznykh verovanii' [A little on how "the process of dying out of religious beliefs» ended]. In: Mezhetnicheskie vzaimodeistviia $i$ sotsiokul'turnaia adaptatsiia narodov Severa Rossii [Cross-ethnic interaction and socio-cultural adaptation of the peoples of the North of Russia], ed. by V. I. Molodin and V. A. Tishkov. Moscow, IEA RAS Publ. 382 p. Pp. 233-250. (In Russ.).

Kharitonova, V.I. (2007) Net, eto ne ia, eto - boginia Kali!.. [This is not me, this is goddess Kali!..]. In: Vliianie religii na obshchestvo i lichnost' [The influence of religion on society and person], ed. by A. A. Velik. Moscow, IEA RAS Publ. 309 p. Pp. 172-199. (In Russ.).

Kharitonova, V. I. (2010a) Shamanskoe tselitel'stvo v sovremennoi Rossii [Shamanic healing in contemporary Russia]. In: 5 Mezhdunarodnyi forum "Integrativnaia meditsina - 
2010' [5th International Forum "Integrative Medicine - 2010"]: a collection of abstracts and speeches]. Moscow, Voskhod-A Publ. 203 p. Pp. 108-112. (In Russ.).

Kharitonova, V. I. (2010b) Rabota s sakral'nymi znaniiami i praktikami: metodikometodologicheskii aspect [Working with sacred knowledge and practices: the methodological aspect]. Etnograficheskoe Obozrenie', no. 3, pp. 7-21. (In Russ.).

Kharitonova, V. I. (2014) Nekonventsional'naia meditsina v sovremennoi Rossii [Nonconventional medicine in contemporary Russia]. In: Meditsinskaia antropologiia i bioetika [Medical Anthropology and Bioethics], no. 1(7) [online] Available at: http://www.medanthro. $\mathrm{ru} / \mathrm{p}=2017$ (access date: 26.08.2018) (In Russ.).

Kharitonova, V.I. (2018) Traditsionnaia meditsina v Rossii: nasushchnaia neobkhodimost' ili kommercheskii proekt? [Traditional medicine in Russia: an urgent need or a commercial project?]. In: Filosofskie problemy biologii i meditsiny. Vyp. 12: Mezhdu biofilosofiei i bioetikoi [Philosophical problems of biology and medicine. Vol. 12: between biophilosophy and bioethics]: a collection of articles. Moscow, Social and humanitarian knowledge Publ. 340 p. Pp. 38-43. (In Russ.).

Submission date: 12.09.2018.

\section{Для цитирования:}

Вяткина Н. А. Народная медицина тувинцев глазами врачей (по материалам опроса врачей и другого медицинского персонала в Республике Тыва и соседних регионах) [Электронный ресурс] // Новые исследования Тувы. 2018, № 4. URL: https://nit. tuva.asia/nit/article/view/807 (дата обращения: дд.мм.гг.). DOI: 10.25178/nit.2018.4.4

\section{For citation:}

Vyatkina N. A. Tuvan folk medicine through doctors' eyes: a survey of physicians and other medical personnel in the Republic of Tuva and its environs The New Research of Tuva, 2018, no. 4 [on-line] Available at: https://nit.tuva.asia/nit/article/view/807 (accessed: ... ). DOI: $10.25178 /$ nit.2018.4.4 